\begin{abstract}
Humboldt-University Berlin, Institute of Livestock Sciences', Max-Delbrueck-Centre for Moleculare Medicine, Berlin², Friedrich-Wilhelms-University Bonn, Institute of Animal Sciences $^{3}$
\end{abstract}

TORSTEN HARDGE', KARLA KOEPKE ${ }^{2}$, MONIKA REISSMANN' and KLAUS WIMMERS ${ }^{3}$

\title{
Maternal influences on litter size and growth in reciprocal crossed Miniature Pigs and Durocs ${ }^{+}$
}

\author{
Dedicated to Prof. Dr. Dr. h.c. Gottfried Leuthold on the occasion of his $65^{\text {th }}$ birthday
}

\section{Summary}

In order to demonstrate the potential power of maternal effects on litter size and growth in pigs a reciprocal cross of Berlin Miniature Pigs and Durocs was carried out. The average body weight of the Duroc dams (151 kg) was more than three times higher than the weight of the Miniature Pig dams $(48 \mathrm{~kg})$.

A considerable maternal effect on fertility, estimated from reciprocal crossbred differences in the litter size of 3.5 piglets was found. The least squares means of birth weight were $1.18 \mathrm{~kg}$ and $0.75 \mathrm{~kg}$ for F1 animals born from Duroc dams and Miniature Pig dams, respectively. This maternal caused disadvantage in body weight of crossbred offspring from Miniature Pig dams is compensated in the interval from weaning to the 13th week of age.

The end weight estimated by means of Gompertz and Bertalanffy growth functions showed only minor differences between the reciprocal crossed groups in favour of F1 born from Duroc dams.

Our data suggest that the uterine capacity of the dam could play an important role in the fertility of extreme breed crosses. Concerning growth performance the milk yield of the sow and the influence of the birthweight of the piglets were discussed.

Key words: pig, maternal effects, fertility, growth

\section{Zusammenfassung}

Titel der Arbeit: Maternale Effekte auf Wurfgröße und Wachstumsmerkmale bei reziprok gekreuzten Miniaturschweinen und Durocs

Anhand einer Versuchspopulation aus der reziproken Verpaarung von Berliner Miniaturschwein und Duroc wurden die potenziellen Maternaleffekte auf Fruchtbarkeit und Wachstumsmerkmale bei extremen Rassenkreuzungen untersucht. Das durchschnittliche Körpergewicht der Durocsauen lag mit $151 \mathrm{~kg}$ etwa dreimal über dem der Miniaturschweinsauen (48 kg).

Für die Wurfgröße wurde ein deutlicher Maternaleffekt in Höhe von 3,5 Ferkeln gefunden. Die LSQ-Mittelwerte für das Geburtsgewicht betrugen 1,18 kg für die Kreuzungsgruppe Miniaturschwein-Eber x Duroc-Sau und 0,75 $\mathrm{kg}$ für Duroc-Eber x Miniaturschwein-Sau. Diese maternal bedingten Nachteile im Körpergewicht wurden von den Kreuzungsnachkommen aus Miniaturschweinsauen allerdings im Zeitabschnitt vom Absetzen bis zur 13. Lebenswoche kompensiert. Die mit Hilfe der Wachstumsfunktionen nach Gompertz und Bertalanffy geschätzten Endgewichte wiesen nur noch vernachlässigbare Differenzen zwischen den F1-Tieren aus den beiden extremen Mutterrassen auf.

Unsere Untersuchungsergebnisse deuten an, daß die Uteruskapazität eine wichtige Rolle für die Fruchtbarkeit bei extremen Rassenkreuzungen spielen könnte. Der maternale Einfluß auf Wachstumsmerkmale wird in Beziehung zur Milchleistung der Sau und dem Geburtsgewicht der Ferkel diskutiert.

Schlüsselwörter: Schwein, Maternaleffekte, Fruchtbarkeit, Wachstum

' The project has been supported by the Association for the Promotion of the East German Pig Breeding (IFOS) and the European Structural Funds (ESF). 


\section{Introduction}

Maternal effects are a significant source of variation for quantitative performance traits in farm animals. They have profound implications for the statistical analysis and biological interpretation of experimental data. The dam contributes in two ways to the phenotypic value of her offspring: (1) through a random sample of her genes and (2) the maternal effect. A maternal influence contributes an environmental effect to the offspring but is genetic in the sense that the genotypic differences among dams are expressed in the phenotypic measurements of their offspring (WILHAM, 1972). The effect of the dam on her offspring can arise prenatally (e.g. cytoplasm of the egg cell, intrauterine environment) and postnatally (e.g. milk production and mothering ability). In reciprocal crosses of extreme breeds the $F_{1}$ owns a copy of $50 \%$ of each parental genome, but they are born from genetic divergent dams. Therefore reciprocal cross differences are assumed to be synonymous with the total maternal effect if sex linkage and genomic imprinting are neglected (WILKEN et al., 1992).

\section{Material and Methods}

\section{Animals}

Crosses of 14 White Miniature Pig dams to Duroc and 7 Duroc dams to the Miniature Pig were carried out by artificial insemination. The Berlin Miniature Pig breed has been developed 20 years ago at the experimental station of the Humboldt-University from a cross of Vietnamese Pot Belly Pigs, Saddle Back Pigs and German Landrace followed by consistent selection for small body weight (LEUCHT et al., 1982). The picture shows a Duroc in comparison to a Berlin Miniature Pig dam.

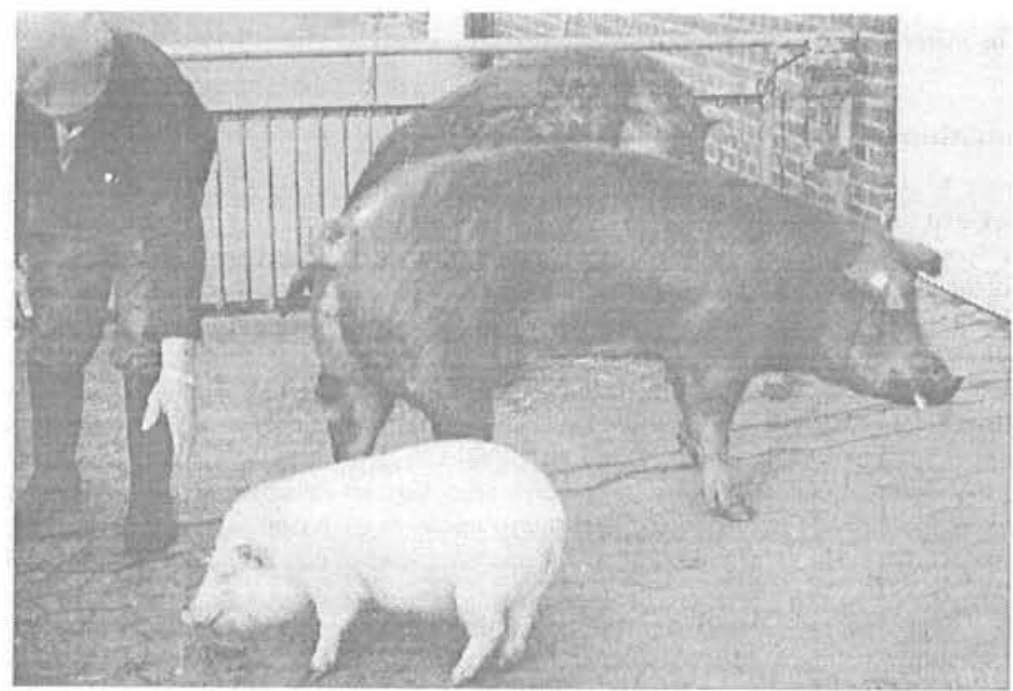

Picture: Duroc dam in comparison to a Berlin Miniature Pig dam (Duroc-Sau im Vergleich zu einer Berliner Miniaturschwein-Sau) 
The average body weight of the included Duroc and Miniature Pig dams was $151.3 \mathrm{~kg}$ and $48.2 \mathrm{~kg}$, respectively. The reciprocal cross of the parental breeds led to $192 \mathrm{~F}_{1}$ pigs. Additionally, a group of 345 purebred Miniature Pigs was included to assess the performance of the Berlin Miniature Pig in comparison to the reciprocal cross groups (Table 1). All animals received the same treatment in respect both feeding and housing at the Research Station of the Humboldt-University in Berlin-Dahlem. Besides to the weekly body weights the body measurements back length, shoulder height and shoulder width were recorded monthly. The shoulder height could only been measured after weaning of the piglets with an age of 35 days.

Table 1

Number of animals in the reciprocal crossbred groups and purebred Miniature Pigs (Stichprobenumfänge für die reziproken Kreuzungsgruppen und für die reinrassigen Miniaturschweine)

\begin{tabular}{lccc}
\hline $\begin{array}{l}\text { breed group/ } \\
\text { trait }\end{array}$ & $\begin{array}{c}\text { Duroc boar x Mini sow } \\
\mathrm{n}\end{array}$ & $\begin{array}{c}\text { Mini boar x Duroc sow } \\
\mathrm{n}\end{array}$ & $\begin{array}{c}\text { Mini boar x Mini sow } \\
\mathrm{n}\end{array}$ \\
\hline body weight & & & $345^{*}$ \\
- until 8th week & 116 & 76 & - \\
- until 28th week & 38 & 34 & - \\
body measurements & 40 & 38 & \\
(1st to 17th week) & & & \\
\hline "only included for birth- and weaning weight & &
\end{tabular}

Because of the limited housing capacity in the experimental station only a reduced sample of pigs in the reciprocal crossbred groups could be included in the analysis from the 8 th to the 28 th week.

\section{Statistical_Analysis}

Least squares means (LSM) were computed for weight measurement from birth to 28th week and for each body measurement from the first week to 17 th week by means of the PROC GLM (SAS for Windows Release 6.08) using the following general model:

$$
\begin{aligned}
y_{i j k l m} & =\mu+a_{j}+b_{k}+c_{1}+d_{m}+e_{i j k l m} \\
y_{i j k l m} & =\text { phenotypic value for the ith pig } \\
\mu & =\text { mean phenotypic value of the base population } \\
\mathrm{a} & =\operatorname{crossbred} \text { group }(\mathrm{j}=1,2) \\
\mathrm{b} & =\text { litter }(\mathrm{k}=1,2) \\
\mathrm{c} & =\text { litter size }(1=2, \ldots, 13) \\
\mathrm{d} & =\operatorname{sex}(\mathrm{m}=1,2) \\
\mathrm{e}_{\mathrm{ij} \mathrm{klm}} & =\text { error component }
\end{aligned}
$$

The probability values for the hypothesis $\mathrm{H}_{0}$ :LSM (Duroc boar $\mathrm{x}$ Mini sow) $=$ LSM (Mini boar $\mathrm{x}$ Duroc sow) were computed to examine the phenotypic differences between the breed at a level of significance of $p=0.05$.

For the comparison of the fertility parameters the nonparametric Wilcoxon rank-sum test (PROC NPAR1WAY) was used. 


\section{Growth functions}

Though the end weight for the adult pigs are unknown this weight can be estimated by means of growth functions. Several growth functions (RASCH et al., 1992) were tested. As the criteria to choose the most suitable function the residual variance and the avoidance of systematic deviations from the regression as well as the stability of the estimated parameters were used. Because the weight recording was finished before the end weight of the pigs was reached the computation of the parameters of a growth function is problematic. At least 30 to 45 weight measurements per pig has been included for the estimation. The parameter of the growth functions suggested that about $75 \%$ of the end weight is reached in the 30 th week of age.

The Gompertz growth function

and the growth function of Bertalanffy

$$
f(x)=a * \exp (b * \exp (c * x))
$$

$$
f(x)=(a+b * \exp (c * x))^{3}
$$

were found to be appropriate for the analysis. The end weights were derived from the parameter a for both functions. For 29 female pigs from 5 Duroc dams and 27 female pigs from 5 Miniature pig dams the parameters of both growth functions were computed with the procedure NLIN (SAS for Windows Release 6.08). To consider the individual development of the pig, the parameters were predicted for each animal separately. The nonlinear functions were fitted by means of PROC NLIN using the secant method (DUD).

\section{Results}

\section{Litter size}

There were no differences in the pregnancy period between Miniature dams and Duroc dams carrying F1-pigs. Despite the higher weight of crossbred piglets from Miniature Pig dams in comparison to purebred Miniature Pigs, no delivery problems were observed.

The reciprocal crossbred difference for litter size was 3.5 piglets in favour of Duroc dams (Tab. 2). Even purebred Miniature Pigs have 1.7 pigs per litter more than Miniature Pig dams sired with Duroc. Interestingly, the differences in the total litter weight were neglectible between offspring born from Miniature Pig dams.

Table 2

Means $(\bar{x})$ and standard error (SE) of the litter size and litter weight in reciprocal crossed Duroc and Miniature Pigs and purebred Miniature Pigs (Mittelwerte $(\bar{x})$ und Standardfehler (SE) der Wurfgröße und des Wurfgewichts für die reziprok gekreuzten Duroc und Miniaturschweine sowie für die reinrassigen Miniaturschweine)

\begin{tabular}{lcccccc}
\hline breed group/ & \multicolumn{2}{c}{ Duroc boar x Mini sow } & \multicolumn{2}{c}{ Mini boar x Duroc sow } & \multicolumn{2}{c}{ Mini boar x Mini sow } \\
trait & $\overline{\mathrm{x}}$ & $\mathrm{SE}$ & $\overline{\mathrm{x}}$ & $\mathrm{SE}$ & $\overline{\mathrm{x}}$ & $\mathrm{SE}$ \\
\hline pregnancy period (d) & $113.8^{\mathrm{a}}$ & 0.45 & $113.7^{\mathrm{a}}$ & 0.36 & - & \\
number born alive (n) & $5.6^{\mathrm{a}}$ & 0.60 & $9.1^{\mathrm{b}}$ & 1.26 & $7.3^{\mathrm{b}}$ & 1.04 \\
litter weight $(\mathrm{kg})$ & $4.03^{\mathrm{a}}$ & 0.47 & $11.07^{\mathrm{b}}$ & 1.41 & $3.77^{\mathrm{a}}$ & 0.38 \\
\hline
\end{tabular}

Different characters mark significant differences $p \leq 0.05$ 
Reciprocals from the cross Minuature boar $\mathrm{x}$ Duroc sow were born in litter with an average number of pigs born alive of 9.1. This was about one piglet less than shown by filed data from purebred Duroc (10.0 pigs born alive) given by the herd book breeding organisation in Brandenburg (ENGLISCH and AUST, 1996).

In spite of the higher number pigs born alive of Duroc dams the litter weight exceeded the compared F1 from Miniature Pig dams almost three times.

\section{Growth}

Offspring from Miniature Pig dams sired with Duroc had a significant lower body weight from birth up to the 7 th week than the vice versa crossed group. The body weight differences increased from birth $(0.44 \mathrm{~kg})$ to the 6 th week up to $3.6 \mathrm{~kg}$. After the 13th week of age no significant differences between the reciprocal crosses are observed (Table 3).

\section{Table 3}

Least squares means (LSM) and standard error (SE) of the body weight from birth to the 28th week in reciprocal crossed Duroc and Miniature Pigs and purebred Miniature Pigs (LSQ-Mittelwerte (LSM) und Standardfehler (SE) der Körpermasseentwicklung von der Geburt bis zur 28. Lebenswoche für die reziprok gekreuzten Durocs und Miniaturschweine sowie für die reinrassigen Miniaturschweine)

\begin{tabular}{lcccccc}
\hline breed group/ & \multicolumn{2}{c}{ Duroc boar x Mini sow } & \multicolumn{2}{c}{ Mini boar x Duroc sow } & \multicolumn{2}{c}{ Mini boar x Mini sow } \\
weekly weight & LSM & SE & LSM & SE & LSM & SE \\
\hline birth & $0.74^{\mathrm{a}}$ & 0.02 & $1.18^{\mathrm{b}}$ & 0.03 & $0.53^{\mathrm{c}}$ & 0.02 \\
1 & $1.36^{\mathrm{a}}$ & 0.05 & $2.41^{\mathrm{b}}$ & 0.05 & & - \\
3 & $3.16^{\mathrm{a}}$ & 0.11 & $5.45^{\mathrm{b}}$ & 0.15 & & - \\
5 & $5.85^{\mathrm{a}}$ & 0.17 & $8.93^{\mathrm{b}}$ & 0.23 & $4.41^{\mathrm{c}}$ & 0.99 \\
7 & $8.66^{\mathrm{a}}$ & 0.23 & $12.14^{\mathrm{b}}$ & 0.32 & & - \\
13 & $25.66^{\mathrm{a}}$ & 0.45 & $26.36^{\mathrm{a}}$ & 0.48 & & - \\
19 & $41.68^{\mathrm{a}}$ & 0.81 & $43.07^{\mathrm{a}}$ & 0.89 & & - \\
25 & $52.82^{\mathrm{a}}$ & 1.08 & $51.44^{\mathrm{a}}$ & 1.59 & & - \\
28 & $56.88^{\mathrm{a}}$ & 1.21 & $55.71^{\mathrm{a}}$ & 1.79 & & - \\
\hline Different characters mark significant differences $\mathrm{p} 50.05$ & & & &
\end{tabular}

Different characters mark significant differences $\mathrm{p} \leq 0.05$

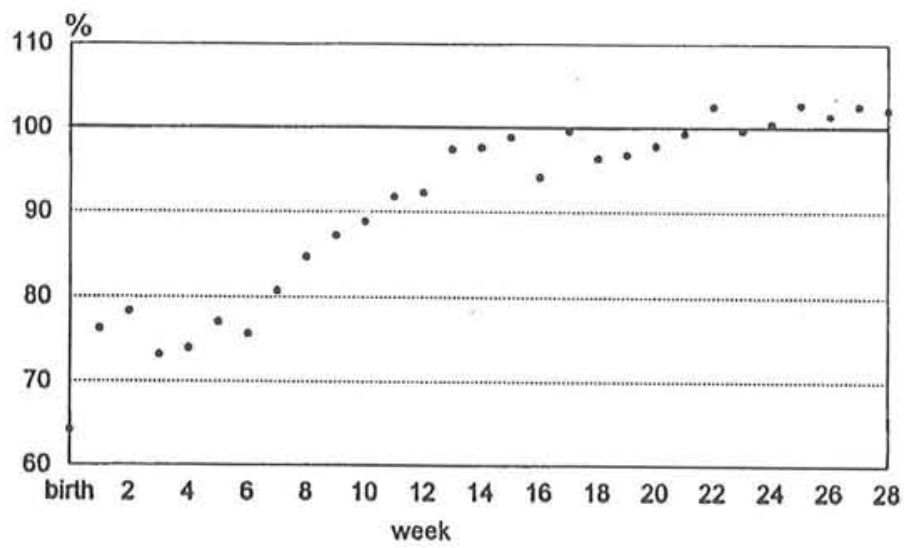

Fig. 1: Relative differences in the body weight between reciprocal crosses Duroc and Miniature Pigs from birth to the 28th week (Miniature Pig boar $\times$ Duroc sow $=100 \%$ ) (Relative Differenzen in den Körpermassen zwischen den rezprok gekreuzten Durocs und Miniaturschweinen von der Geburt bis zur 28.Lebenswoche (Miniaturschwein-Eber $\times$ Duroc-Sau $=100 \%)$ ) 
During suckling the body weight differences between crossbred offspring born from Miniature Pig dams compared to offspring born from Duroc dams remained nearly unchanged. After weaning the crossbred offspring born from Miniature Pig dams were able to compensate their lower body weight around the 13th week (Fig. 1).

From the 22nd week of age reciprocals from Miniature Pig dams tended to higher body weights than $\mathrm{F}_{1}$ from Duroc dams.

In order to estimate the end weight of the reciprocals growth functions were applied. Figure 2 shows that the $F_{1}$ from reciprocal crosses had very similar shapes of the growth functions (Fig. 2).

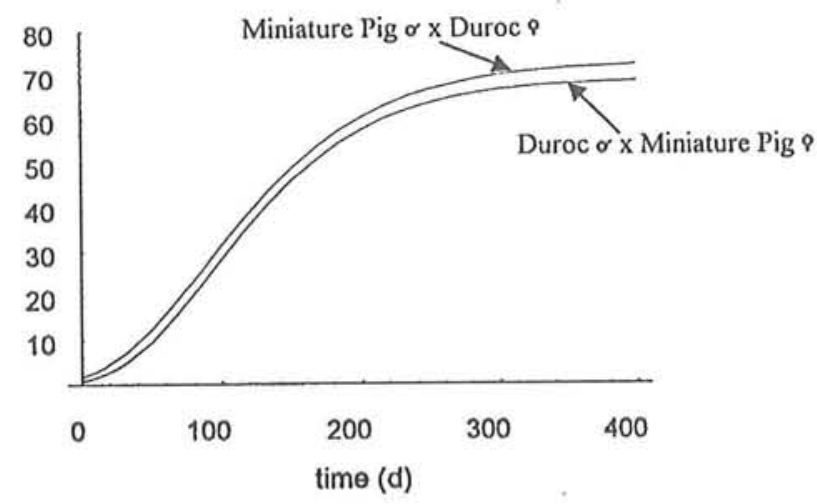

Fig. 2: Gompertz growth functions for the reciprocal crosses (Wachstumsfunktionen nach Gompertz für die reziproken Kreuzungsgruppen)

The median for the estimated end weight from the Gompertz function was $72.8 \mathrm{~kg}$ and from the function of Bertalanffy $79.1 \mathrm{~kg}$ for $F_{1}$ pigs born from Duroc dams. Reciprocals from Miniature Pig dams had a calculated end weight of $68.9 \mathrm{~kg}$ and 75.3 $\mathrm{kg}$ derived from the function from Gompertz and Bertalanffy, respectively. End weights estimated from the function of Bertalanffy always exceeded the weights calculated by the Gompertz function but the difference between the two crossbred groups is similar $(3.9 \mathrm{~kg}$ and $3.8 \mathrm{~kg})$.

\section{Body measurements}

The body measurements back length, shoulder height and shoulder width were chosen to describe possible growth differences between the reciprocals in comparison to the weight development (Fig. 3).

Until weaning $F_{1}$-pigs born from Duroc dams were significant longer, higher and wider than $F_{1}$ born from Miniature Pig dams. After the 9th week of age the reciprocal crossbred groups differed mainly in the back length. In the 17th week of age no significant differences in any of the included body measurements were found. The measurements of the shoulder height and shoulder width corresponded to the average 
body weight development. The maternal effect on body weight could be described best by the back length of the reciprocal crossed pigs.

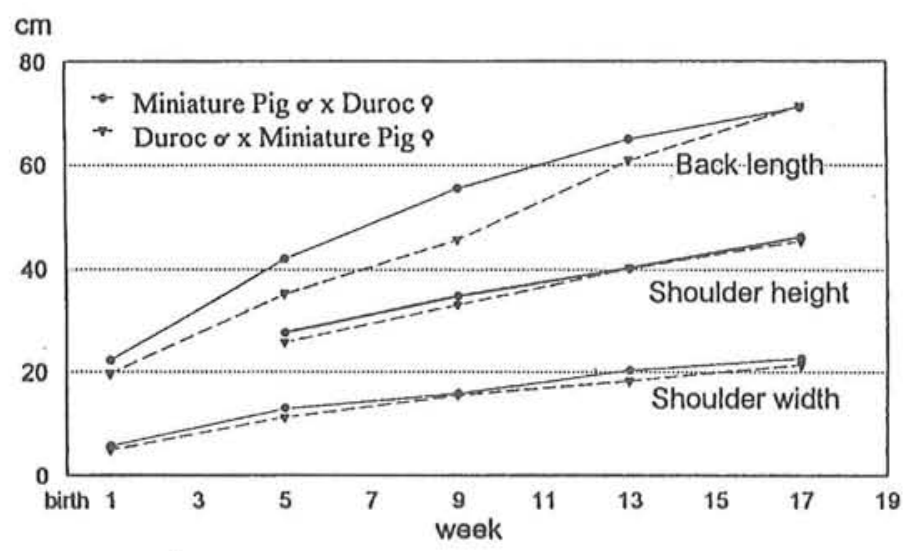

Fig. 3: Differences in the back length, shoulder height and shoulder width between the reciprocal crosses from the first to the 17th week of age (Differenzen in der Rückenlänge, Widerristhöhe und Rippenbrustbreite zwischen den reziproken Kreuzungsgruppen von der ersten bis zur 17. Lebenswoche)

\section{Discussion}

Growth is a classical quantitative trait controlled by many genes. CORNSTOCK and ENFIELD (1981) estimated from crosses of inbreeding lines that dependent of the heritability about 230 genes are responsible for growth in mice. Especially in the early growth the direct genetic effect can be affected by prenatal and postnatal influences of the dam.

As early as 1938 WALTON and HAMMOND applied the classical experimental design of reciprocal crosses for the investigation of maternal effects on growth in horses. They reciprocal crossed Shetland Pony and Shire in order to determine how the size of the mother would affect the size of the offspring. The weight relation between Shetland and Shire dams was 1:4.2, representing extreme small and large horse breeds. They found substantial differences between the reciprocal $F_{1}$ and concluded, that the weight of the offspring at birth is directly proportional to the size of the dam. At an age of three years the differences between the reciprocal crosses were still marked. In a reciprocal cross of Belgian Draft and Shetlands FLADE (1957) showed pronounced maternal effects on a number of body measurements up to an age of two years.

In cattle reciprocal crosses between South Devon and Dexter (weight relation 1:1.9) the mean difference in birth weight between the groups was $24 \%$ in favour of calves from the large South Devon dams. At the end of the weight recording at the 12th month the weight differences were still 16\% (JOUBERT and HAMMOND, 1954; JOUBERT and HUNTER, 1958). Reciprocal crosses between beef breeds with a lower weight difference between the pure breeds did not show any or minor maternal effects in the birthweight or postnatal weight gain (GAINES et al., 1966; PAHNISH et al., 
1969; DEARBORN et al., 1987; GREGORY and MAURER, 1991).

In our own experiment we applied reciprocal crossed Berlin Miniature Pigs and Duroc in order to estimate maternal effects in extremely different sized pigs. The weight relationship between the parental breeds was almost 1:3. Taken into account these big weight differences, the possible influence of cytoplasmatic effects, sex linked genes and genomic imprinting is assumed to be very small in relation to the main effects studied in this experiment.

The maternal effect on litter size estimated from the reciprocal cross is 3.5 pigs (Table 2). Interactions between uterine capacity, ovulation rate and embryo survival are discussed as major components of litter size in pigs (BLASCO et al., 1993; GAMA and JOHNSON, 1993). Although none of these traits has been recorded in the experiment our data suggest that the uterine capacity could play an important role in the fertility of extreme breed crosses. This can be shown by comparing the size of Miniature Pig litters and crossbred litters both born from Miniature Pig dams. The significant differences in the number of piglets born alive of 1.7 piglets but small differences in the litter weight, suggest that the higher weight of crossbred piglets can directly limit the litter size in the small dam breed.

Crossbred offspring born from Duroc dams are nearly $60 \%$ heavier at birth than crossbred piglets from Miniature Pig dams although the effect of the litter size has been considered in the statistical analysis of weight data. The maternal caused disadvantage in the body weight of crossbred offspring from Miniature Pig dams is compensated in the interval from weaning at the 5th week to the 13th week of age (Fig. 1). The estimated growth functions for the offspring of reciprocal crossed Miniature Pigs and Duroc shows very similar growth curves (Fig. 2). The calculated end weight is reached around the 400th day with only low differences in the end weight between the reciprocal crossed groups.

For two reasons it is questionable if differences in the milk production between the dam breeds are responsible for the observed maternal effect up to the 8 th week. (1) Insufficient milk production of the dam is compensated through a higher creep consumption (ROBISON, 1972). (2) Additionally, reciprocals born from Miniature Pig dams are born in remarkable smaller litters compared to Duroc dams. Birth weight may largely contribute to the vitality and may influence the feed consumption. Also results from cross nursing experiments suggest that rather the maternal influence on birth weight itself play a major role in the early growth of piglets (ROBISON, 1972; Van Der STEEN and GROOT, 1992).

HARING et al. (1966) found in a reciprocal cross of Vietnamese pot bellied Pigs and Large White with an extreme weight relation of 1:4.5 that reciprocals from Large White dams were 2.5 times heavier than $F_{1}$ piglets born from Vietnamese dams. In the 32 th week the weight difference between the reciprocals was still $38 \%$. He concluded that the growth of piglets in divergent breed crosses is in big sows limited by their own genotype and in smaller sows by the intra uterine environment. In a reciprocal cross of Landrace and South African Native pigs (weight relation 1:1.8) JOUBERT (1962) found maternal effects on litter size and weight until the end of the weight recording in 
experiment of HARING et al. (1966) with bigger differences in the size of the included breeds.

Systematic reciprocal crossbreeding experiments including Landrace and Large White (DZAPO et al., 1983; IRGANG et al., 1992); Duroc and Landrace (WILKEN et al., 1992); Duroc, Yorkshire, Landrace and spotted breeds (BERESKIN et al., 1971) showed that the maternal influence on growth is comparatively low in crosses with small weight differences between the parental breeds.

In crosses of extreme different sized breeds substantial maternal effects on litter size and growth have to be taken into consideration. Obviously, the direct genetic effect of the piglets on growth traits seems to be more important after weaning leading to the compensation of the pre weaning maternal effect. The maternal induced disadvantages in growth is related to the body weight differences between the parental breeds. The ability to compensate maternal induced disadvantages in growth should be regarded as an original trait.

\section{References}

BERESKIN, B.; SHELBY, C.E.; HAZEL, L.N.:

Carcass traits of purebred Durocs and Yorkshires and their crosses. J. Anim. Sci. , Albany, N.Y. 32 (1971), 413 - 419

BLASCO, A.; BIDANEL, J.P.; BOLET, G.; HALEY, C.S.; SANTACREU, M.A.:

The genetics of prenatal survival of pigs and rabbits: a review. Livestock Prod. Sci., Amsterdam 37 (1993), 1 - 21

CORNSTOCK, R. E., ENFIELD, F.D.:

Gene number estimation when multiplicative genetic effects are assumed - growth in flour beetles and mice. Theor. Appl. Genet. 59 (1981), 373 - 379

DEARBORN, D.D.; GREGORY, K.E.; CUNDIFF, L.V.; KOCH, R.M.:

Maternal heterosis and grandmaternal effects in beef cattle: preweaning traits. J. Anim. Sci., Albany, N.Y. 65 (1987), 33 - 41

DZAPO, V.; SCHNARR, W.; WASSMUTH, R.:

Mitochondrialer Stoffwechsel und heterotische Effekte beim Schwein. Ergebnisse eines reziproken Kreuzungsversuchs. 1. Reproduktionsleistung, Wachstumsintensität und Schlachtkörperqualität. Z. Tierzüchtg. Züchtungsbiol. 100 (1983), 109 - 122

ENGLISCH, H.G.; AUST, H.:

Schweinezucht und Haltung. Landesamt für Ernährung; Landwirtschaft und Flurneuordnung des Landes Brandenburg; Tierzuchtreport (1996), pp 47

FLADE, J.E.

Die Entwicklung der Nachkommen aus reziproken Kreuzungen zwischen Kaltblut und Shetlandpony von der Geburt an bis zum Abschluß des zweiten Lebensjahres. Tierzucht, Berlin 11 (1957), 274 - 275

GAINES, J. A.; MCCLURE, W.H.; VOGT, D.W.; CARTER, R.C.; KINCAID, C.M.:

Heterosis from crosses among British breeds of beef cattle: Fertility and calf performance to weaning. J. Anim. Sci., Albany, N.Y. 25 (1966), 5 - 13

GAMA, L.L.T.; JOHNSON, R. K.:

Changes in ovulation rate, uterine capacity, uterine dimensions, and parity effects with selection for litter size in swine. J. Anim. Sci., Albany, N.Y 71 (1993), 608 - 617

GREGORY, K.E.; MAURER, R. R.:

Prenatal and postnatal maternal contributions to reproductive, maternal, and size-related traits of beef cattle. J. Anim. Sci., Albany, N.Y 69 (1991), 961 - 976

HARING, F.; STEINBACH, J.; SCHEVEN, B.:

Untersuchungen über den mütterlichen Einfluß auf die prä- und post-natale Entwicklung von Schweinen extrem unterschiedlicher Größe. Z. Tierzilchtg. u. Züchtungsbiol. 82 (1966), 37 - 53 
IRGANG, R.; SCHEID, I.R.; FAVERO, J.A.; WENTZ, I.:

Daily gain and age weight at puberty in purebred and crossbred Duroc, Landrace and Large White gilts. Livestock Prod. Sci., Amsterdam 32 (1992), 31 - 40

JOUBERT, D. M.:

The maternal effects on size at birth and weaning in Landrace-native pig crosses. Anim. Prod., Edinburgh 4 (1962), 117 - 121

JOUBERT, D. M.; HAMMOND, J.:

Maternal effects on birth weight in South Devon x Dexter Cattle crosses. Nature, London 4431 (1954), $647-648$

JOUBERT, D. M.; HUNTER J.:

A crossbreeding experiment with cattle, with special reference to the maternal effect in South DevonDexter crosses. J. Agric. Sci. 51 (1958), 235 - 341

LEUCHT, W.; GREGOR, G.; STIER, H.:

Einfuhrung in die Versuchstierkunde Band IV. Das Miniaturschwein. VEB Gustav Fischer Verlag, Jena (1982)

PAHNISH, O.F.; BRINKS, J.S.; URICK, J.J.; KNAPP, B.W.; RILEY, T.M.:

Results from crossing beef $x$ beef and beef $x$ dairy breeds: calf performance to weaning. J. Anim. Sci., Albany, N.Y. 28 (1969), $291-299$

RASCH, D.; GUIARD, V.; NÜRNBERG, G.: Statistische Versuchsplanung, Gustav Fischer Verlag, Stuttgart, Jena, New York (1992), pp 257

ROBISON, O.W:

The role of maternal effects in animal breeding: V. Maternal effects in swine. J. Anim. Sci., Albany, N.Y. 35 (1972), $1303-1315$

STEEN, H.A.M. VAN DER; DE GROOT, P.N.:

Direct and maternal breed effects on growth and milk intake of piglets: Meishan versus Dutch breeds. Livestock Prod. Sci., Amsterdam 30 (1992), 361 - 373

WALTON, A.; HAMMOND, J.:

The maternal effects on growth and conformation in Shire horse-Shetland pony crosses. Proc. Roy. Soc. B CXXV (1938), $311-335$

WILHAM, R.L.:

The role of maternal effects in animal breeding: III. Biometrical aspects of maternal effects in animals.

J. Anim. Sci., Albany, N.Y. 35 (1972), 1288 - 1293

WILKEN, T.M.; LO, L.L.; MCLAREN, D.G.; FERNANDO, R.L.; DZUIK, P.J.:

An embryo transfer study of reciprocal cross differences in growth and carcass traits of Duroc and Landrace pigs. J. Anim. Sci., Albany, N.Y. 70 (1992), 2349 - 2358

Received: 12.10 .1998

Accepted: 04.12.1998

Author's addresses

Dr. TORSTEN HARDGE, Dr. MONIKA REISSMANN

Humboldt-Universităt zu Berlin

Institut für Nutztierwissenschaften

Invalidenstraße 42

D-10115 Berlin

E-Mail: torsten.hardge@rz.hu-berlin.de

Dr. KARLA KOEPKE

Max-Delbrilck-Centrum

für

Molekulare Medizin

Robert-Rössle-Str. 10

D-13092 Berlin

E-Mail: kkoepke@mdc-berlin.de

\section{Dr. KLAUS WIMMERS}

Rheinische Friedrich-Wilhelms-

Universität Bonn

Institut für Tierzuchtwissenschaft

Endenicher Allee 15

D-53115 Bonn

E-Mail: wimmers@itz.uni-bonn.de 